\title{
The role of ectomycorrhizal fungi in calcareous soil tolerance by "symbiocalcicole" woody plants
}

\author{
F Lapeyrie \\ INRA, Centre de Recherches Forestières de Nancy, Champenoux, 54280 Seichamps, France
}

(Received 29 March 1990; accepted 5 October 1990)

\begin{abstract}
Summary - There are now a few examples in the literature of trees or dwarf shrub which can tolerate calcareous soils only in association with mycorrhizal fungi; these plants could be termed symbiocalcicole. An integrative flow-diagram which summarizes probable interactions between calcareous soil, mycorrhizal fungi and roots of symbiocalcicole plants is presented and discussed. Solubilisation, mobilisation and/or assimilation of phosphorus, calcium, nitrogen, iron and carbonate from calcareous soil are considered successively.
\end{abstract}

mycorrhizas / calcareous soil / calcium / calcifuge / symbiocalcicole

Résumé - Les champignons ectomycorhiziens et la tolérance des sols calcaires par les plantes ligneuses "symbiocalcicoles". Quelques cas d'arbres ou d'arbustes nains tolérant les sols calcaires uniquement lorsqu'ils sont associés à des champignons ectomycorhiziens ont fait l'objet d'une publication. Ces plantes pourraient être dénommées "symbiocalcicoles". Un diagramme résumant les interactions probables existant entre sol calcaire, champignon mycorhizien et racine d'une plante symbiocalcicole est présenté et discuté. Sont envisagées successivement, la solubilisation, la mobilisation et/ou l'assimilation du phosphore, du calcium, de l'azote, du fer et des carbonates d'un sol calcaire.

mycorhizes / sol calcaire / calcicole / calcifuge / symbiocalcicole

\section{INTRODUCTION}

It has long been known that some plants, including tree species, can be categorized according to their ability to grow in calcareous soils or acidic soils, ie the calcicole plants growing in calcareous soil, and the calcifuge plants unable to tolerate calcareous soils. From a practical point of view, both foresters and agronomists have taken this into consideration in the selection of plant species for the different soil types to achieve maximum results. The physiological basis for this classification is still the subject of active investigation since no complete explanation as to the mechanism for the differential tolerance of the two types of soil is currently available. Many hypotheses have been proposed, and these have been the subject of a number of reviews (Burstrom, 1968; Kinzel, 1983). 
Invariably, ion balances have been implicated but in most cases the experimental models have included growing plants in aseptic conditions or in soils where the mycorrhizal status was not determined. However, during the last 10 years, 4 studies comparing sterile and non sterile conditions for plant growth in calcareous substrate have indicated that some plants can tolerate calcareous soils only in association with mycorrhizal fungi. This suggests that the ecological and physiological status of the plants have been altered in the presence of a symbiotic partner. These four published studies will be reviewed here. To understand the possible role of mycorrhizal fungi in plant tolerance to calcareous soil, hypotheses based on current knowledge about calcareous soil toxicity and plant/fungus relationship will be proposed and discussed.

\section{CASE REVIEWS}

There have been 4 reported examples todate of plants showing tolerance to calcar- eous soil due to their association with mycorrhizal fungi. A summary of these results and experimental conditions is presented in table $\mathrm{I}$.

It is interesting to note that, although these experiments were not carried out under the same conditions, the general conclusions are remarkably similar. In the 4 specific examples published, plant growth and development was compared in the presence and absence of mycorrhizas either in calcareous soil only (Kianmehr, 1978; Piou, 1979), or in calcareous and acidic substrates (Le Tacon, 1978; Lapeyrie and Chilvers, 1985). In the first situation the calcareous soil toxicity was indicated in leaf chlorosis and plant death, and this was relieved by mycorrhizal infection. In the second situation, the calcareous soil toxicity was even more obvious when comparing plant growth and mortality between sterile acidic and sterile calcareous substrates. While growth was strongly inhibited in calcareous sterile substrate, following inoculation there was no difference between plant growth in both types of substrate, acidic or calcareous.

Table I. Case reviews of plant tolerance to calcareous soil due to mycorrhizal fungus.

\begin{tabular}{|c|c|c|c|c|}
\hline Host plant & Culture substrate & Inoculum type & Endo/ecto & Reference \\
\hline $\begin{array}{l}\text { Pinus nigra } \\
\text { nigrians Host }\end{array}$ & Sand $\pm \mathrm{CaCO}_{3}$ & $\begin{array}{l}\text { Seedlings } \\
\text { pre-infected } \\
\text { or not, into } \\
\text { unsterile soil }\end{array}$ & Ecto & $\begin{array}{l}\text { Le Tacon } \\
\text { (1978) }\end{array}$ \\
\hline $\begin{array}{l}\text { Helianthemum } \\
\text { chamaecistus Mill }\end{array}$ & $\begin{array}{l}\text { Sterile } \\
\text { calcareous soil }\end{array}$ & $\begin{array}{l}\text { Cenococcum } \\
\text { graniforme } \\
\text { sclerotia }\end{array}$ & Ecto & $\begin{array}{l}\text { Kianmehr } \\
(1978)\end{array}$ \\
\hline $\begin{array}{l}\text { Pinus halepensis } \\
\text { Hill }\end{array}$ & Calcareous soil & $\begin{array}{l}\text { Sterile versus } \\
\text { unsterile soil }\end{array}$ & Ecto & Piou (1979) \\
\hline $\begin{array}{l}\text { Eucalyptus dumosa } \\
\text { A Cunn ex Schau }\end{array}$ & $\begin{array}{l}\text { Calcareous or acidic soil \& } \\
\text { potting mix } \pm \mathrm{CaCO}_{3}\end{array}$ & $\begin{array}{l}\text { Unsterile soil } \\
\text { reintroduced } \\
\text { into sterile } \\
\text { substrate }\end{array}$ & $\begin{array}{l}\text { Ecto \& } \\
\text { Endo }\end{array}$ & $\begin{array}{l}\text { Lapeyrie and } \\
\text { Chilvers } \\
(1985)\end{array}$ \\
\hline
\end{tabular}


Different techniques were used to introduce the mycorrhizal fungi, ranging from monospecific inoculum (Kianmehr, 1978), $10 \%$ of unsterile soil (Lapeyrie and Chilvers, 1985), $100 \%$ of unsterile soil (Piou, 1979 ), or plantation of seedlings previously raised in a non sterile soil (Le Tacon, 1978). In three out of four cases, ectomycorrhizas were found conferring tolerance to calcareous soils (Kianmehr, 1978; Le Tacon, 1978; Piou, 1979), in one case the host plant was infected simultaneously with endomycorrhizal and ectomycorrhizal fungi (Lapeyrie and Chilvers, 1985). In this example, the endomycorrhizas were the dominant mycorrhizal form during the first two months conferring resistance to calcareous soil, being progressively replaced by ectomycorrhizas after this period (Chilvers et al, 1987). This suggests that both endomycorrhizas-VA and ectomycorrhizas have similar protecting effects on plants growing in calcareous soils.

While the four species cited in table I, Eucalyptus dumosa, Pinus halepensis, Helianthemum chamaecistus and Pinus nigra nigricans can tolerate calcareous soils following mycorrhizal infection, others, including Cupressus sempervirens or $\mathrm{Cu}$ pressus arizonica, are indifferent to the presence of calcium carbonate even in sterile conditions (Piou, 1979). Yet, another group of plants, including Eucalyptus dalrympleana, $E$ populnea, $E$ grandis, $E$ largiflorens, $E$ dives, $E$ gunii, $E$ maidenii, $E$ globulus sp bicostata (Lapeyrie, 1987) or Picea excelsa (Le Tacon, 1978) do not tolerate calcium carbonate even after infection by the same mycorrhizal strain which were protecting other species.

Since these studies did not aim to investigate the physiological aspects of resistance to calcareous soil, questions remains as to the mechanisms involved. However, where Pinus nigra nigricans was used as a test plant and grown in calcare- ous soil, normal nitrogen metabolism, ie amino acid and protein synthesis, was restored following plant inoculation (Clément et al, 1977). Improvement of plant phosphorus nutrition was observed with Eucalyptus dumosa (Lapeyrie and Chilvers, 1985). Reduction of the calcium concentration in the leaves was noticed with Eucalyptus dumosa (Lapeyrie and Chilvers, 1985) and Pinus nigra nigricans (Le Tacon, 1978).

\section{DISCUSSION}

\section{Calcicole and symbio-calcicole plants}

It appears that the ecological classification between calcicole and calcifuge plants could be enriched by taking into account their mycorrhizal dependency on calcareous soils, some plants being able to tolerate calcareous soils only in association with mycorrhizal fungi while other do so even under sterile conditions. The new group of plants, could be termed "symbiocalcicole plants", implying that their ability to tolerate calcareous soil is strictly dependent on their symbiotic status. The definition of calcicole and calcifuge plants would therefore be altered slightly: the calcicole plants would refer to plants which tolerate calcareous soils even in the absence of mycorrhizal fungi, the calcifuge plants would become plants which do not tolerate calcareous soils even in the presence of mycorrhizal fungi.

Obviously, the existence of strictly calcicole trees could be questioned because, while in their ecosystem, trees are always associated with mycorrhizal fungi and because pot experiments in sterile substrate are always carried out for a limited period of time; always very short compared with the tree life span. It could therefore be 
argued that survival in sterile calcareous soils (Piou, 1979), is a temporary phenomenon. However, if we refer to annual plants, carnations produced commercially either in soil or under hydroponic conditions are, in both cases, behaving as a calcicole species. The optimum nutrient solution for hydroponic culture is characterized by high $\mathrm{pH}$ and calcium concentration (Brun and Montarone, 1987). Endomycorrhizal fungi are absent in such conditions, without any symptoms of toxicity for the plant, while the same medium would be toxic for a calcifuge crop species.

Such distinction into three groups could be important to consider, before undertaking any comparative physiological work aimed at understanding why some plants tolerate calcareous soils and others do not. To explain the physiological differences between a calcifuge plant and a symbiocalcicole plant, ie why the latter can be rendered tolerant to calcareous soil by the fungus while the former cannot, two hypotheses can be considered. The first where both plants do not suffer the same metabolic disorders when planted in sterile calcareous soil; the metabolic disorders encountered by the symbiocalcicole plant would be such that the associated mycorrhizal fungus could counteract them, whereas in the case of the calcifuge plant, the fungus could not rectify these metabolic disorders. The second hypothesis supposes that the calcifuge and symbiocalcicole plants suffer the same metabolic disorders when planted in sterile calcareous soil; however, the plant-fungus relationship would involve different metabolic pathways in both cases; the symbiotic metabolism involving the symbiocalcicole plant would be able to counteract the host plant stress while in the calcifuge plant it could not. This implies that different plant fungus combinations have specific metabolic pathways involved. Evidence sup- porting this statement has been demonstrated by Dell et al (1988) who showed that, for at least the fungal NADP glutamate dehydrogenase, its activity can be expressed or repressed in ectomycorrhizas depending on the host plant.

\section{Fungus-calcareous soil interface}

Irrespective of the direct action of the fungus on the plant metabolism (Al Abras et al, 1988) including hormonal metabolism (Gay, 19.87) or on the plant gene expression (Hilbert and Martin, 1988), the role of mycorrhizal fungi in calcareous soil could also be considered through their action at the soil-plant interface. It is clearly established that some fluxes of ions are dependent on the presence of the symbiotic fungus (Rygiewicz and Bledsoe, 1984). In the specific case of calcareous soils, some pathways for the movement of ions, which could be very important for the host plant status, are presented in figure 1.

\section{Nitrogen nutrition}

Nitrate is the prominent form of nitrogen in calcareous soils. Chlorosis in trees can be partly related to their nitrogen nutrition as found with Nordmann fir where different types of chlorosis can be induced either by nitrate or calcium carbonate (Khalil et al, 1989). Perturbation of nitrogen metabolism observed on calcareous soil in the absence of mycorrhizas (Le Tacon, 1978) appears to be overcome through the symbiosis.

It is well established that the mycorrhizal fungus actively participates in plant nitrogen nutrition. Mycorrhizal infection improves the nitrogen absorption, and simultaneously modifies the ratio of influx and efflux of ions (Rygiewicz et al, 1984a; 


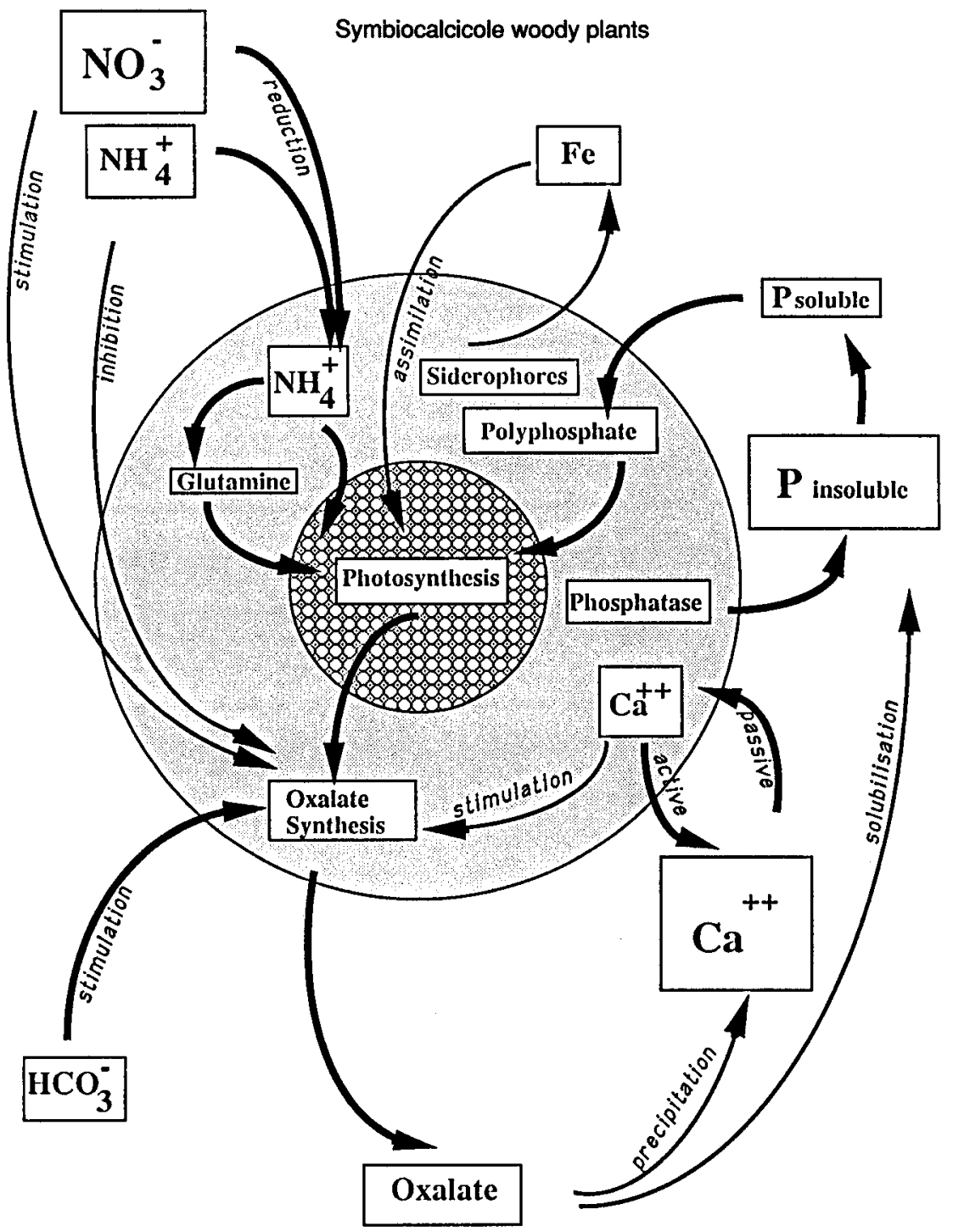

Fig 1. Schematic representation of pathways for the movement of ions at the soil-fungus interface in calcareous soil. : Host-plant root; : Ectomycorrhiza fungal sheath.

1984b). These experiments have been performed at acidic and neutral $\mathrm{pH}$, and therefore the conclusions cannot be easily extrapolated to calcareous soils. However, it has been demonstrated on many occa- 
possess proteases (Botton et al, 1986; Plassard et al, 1986) giving them access to soil proteins. Then, the transfer of nitrogen to the plant occurs either as ammonium or as glutamine and this process is still under investigation (France and Reid, 1983; Martin et al, 1986), but it has been shown that composition of the free amino acid pool in the plant is dependent on its symbiotic status (Krupa et al, 1973; Krupa and Branstrom, 1974; Vésina et al, 1989).

\section{Calcium fluxes}

According to another hypothesis, calcium ions may be responsible for calcareous soil toxicity (Jefferies and Willis, 1964; Hall, 1977). In vivo as well as in vitro, calcium ions are absorbed in excess by roots of calcifuge plants from calcareous soil or calcium ion solutions (Anderson and Ladiges, 1978; Salsac, 1973, 1980). As a consequence, chloroplast thylakoid structure would be affected (Cournier et al, 1982), as well as $\mathrm{C} 3$ or $\mathrm{C} 4$ photosynthesis (Portis et al, 1977; Chevalier and Paris, 1981; Gavalas and Manetas, 1980a, b; Portis and Heldt, 1976). These differences in calcium absorption and accumulation have been related to different composition of the plasma membrane of calcicole and calfigue plants (Rossignol, 1977; Rossignol et al, 1977; Lamant and Heller, 1975; Lamant et al, 1977). Calcium ions enter the cell passively, the flow only being dependent on the nature of the membrane. At present, we do not have any information about the composition of the plasma membrane of symbiocalcicole plants compared to calcicole or calcifuge plants. The internal cation concentration of cells is also dependent on an active calcium efflux (Hager and Hermsdorf, 1981).

While mycorrhizal fungi are more or less tolerant to calcareous soils, depending on their ecological origin, they tolerate extremely high concentrations of calcium ions (Lapeyrie et al, 1982). At ecological concentrations, the mycorrhizal fungus would mediate most of the nutrient fluxes from the soil to the plant, and could therefore prevent the plant from an overaccumulation. Primarily, mycorrhizal fungi possess an active efflux regulating the calcium accumulation (Lapeyrie and Bruchet, 1986), secondarily, calcium ions precipitate outside the fungal cell as calcium oxalate. Such crystals have been observed on many occasions in situ (Malajczuk and Cromack, 1982) as well as in vitro (Lapeyrie et al, 1984a). These calcium ions precipitated in the close rhizosphere are no longer free for absorption.

Using transmission electron microscopy, fungal intracellular vesicles, concentrating calcium associated with carbon hydrogen and oxygen, thought to be amorphous calcium oxalate vesicles have been observed (Lapeyrie et al, 1990). They have been described in fungal cell in pure culture as well as in association with a host plant. They occur in the sheath and as far as the Hartig net when calcium carbonate is provided in the external medium. Their role, internal storage or excretion, is still to be determined; presently no excretion figure have been found, suggesting that amorphus calcium oxalate content can be easily solubilized if some excretion occurs.

\section{Phosphorus nutrition}

While in calcareous soils phosphorus evolves toward more and more crystalline, and less and less soluble forms (Duchaufour, 1970), fungal oxalic acid could be another important factor. The role of oxalic acid in mineral weathering has been well recognized and studied in vitro (Cornell and Schindler, 1987), as well as in vivo with lichens where the oxalic acid is secreted by the mycobiont (Jones et al, 1980; 
Jones and Wilson, 1985). Oxalic acid is an acid as well as chelating agent and after excretion in the soil it is particularly efficient in minerals alteration (Robert et al, 1979). In calcareous soil, by triggering the formation of complexes with metal ions (Ca, Al, Fe), oxalic acid would release phosphorus from insoluble phosphates (Graustein et al, 1977; Coleman et al, 1983).

Abundant oxalic acid synthesis by mycorrhizal fungi is characteristic of calcareous soils: the synthesis is stimulated by nitrate but inhibited by ammonium ions, it is slightly stimulated by calcium ions and highly stimulated by carbonate ions (Lapeyrie et al, 1987). Carbonate ions from the soil, which can be toxic for the fungus as well as for the plant, are used by the fungus as a carbon substrate, including for oxalate synthesis either directly from oxalo-acetate or via citrate, isocitrate and glyoxylate (Lapeyrie, 1988). Futhermore, the release of fungal phosphatases will allow the solubilization of organic phosphate (Bousquet et al, 1986).

After absorption by the fungus, phosphorus is stored in vacuoles as polyphosphate granules, eventually containing calcium, before being translocated to the host plant when required (Ling Lee et al, 1975; Strullu et al, 1982; Lapeyrie et al, 1984b; Martin et al, 1985; Orlovich et al, 1989). The plant phosphorus nutrition in calcareous soil is even more dependent on its mycorrhizal status than in acidic soils.

\section{Iron assimilation}

Iron deficiency has been seen as the key point of calcareous soil toxicity. Indeed, calcareous soil chlorosis symptoms can be relieved by iron-chelate fertilization, suggesting that iron could not be absorbed in calcareous soil by the roots of the calci- fuge plant. However, in most of the cases investigated, no consistent iron deficiency has been found in the leaves (Marschner, 1986). Today, rather than the iron concentration, its status in the plant is considered with reference to metabolically "active" or "inactive" iron (Oserkowsky, 1933; Katyal and Sharma, 1980; Mengel et al, 1984). It has been suggested that the calcifuge plants on calcareous soil synthesize in the root system some sort of "iron inactivator" (Rhoads and Wallace, 1960; Falade, 1973; Brown and Jones, 1975). As we know that some mycorrhizal fungi excrete siderophores (Szaniszlo et al, 1981; Watteau, 1990), as do most soil microorganisms; these iron-complexing molecules could interact with iron in the soil as well as in the plant organs, counteracting any inactivation.

\section{CONCLUSION}

A characteristic difficulty in understanding the behaviour of calcifuge and calcicole plants is the multiplicity of factors affecting their response (Kinzel, 1983). It is now obvious that all these factors interact together with the plant, but we do not understand yet all the complexities of these interactions. However, it seems that an extra factor, the mycorrhizal fungus, has been neglected in most of the physiological studies aimed at understanding the calcicole calcifuge phenomenon. The presence of a fungus associated with the root system defines new soil-plant interactions, the fungus-soil interface becomes the dominant one. However, as previously mentioned, direct interactions between plant and fungus should not be neglected either, in an attempt to understand the way in which plants operate in calcareous soil. 


\section{REFERENCES}

Al Abras K, Bilger I, Martin F, Le Tacon F, Lapeyrie $F$ (1988) Morphological and physiological changes in ectomycorrhizas of spruce associated with ageing. New Phytol 110, 535-540

Anderson CA, Ladiges PY (1978) A comparison of three populations of Eucalyptus obliqua L'Herit growing on acid and calcareous soils in southern Victoria. Aust J Bot 26, 93-109

Botton B, El Badaoui K, Martin F (1986) Induction of extracellular proteases in the ascomycete Cenococcum geophilum. In: Physiological and Genetical Aspects of Mycorrhizae (Gianinazzi-Pearson V, Gianinazzi S, eds) INRA, France, 403-406

Bousquet N, Mousain D, Salsac L (1986) Use of phytate by ectomycorrhizal fungi. In: Physiological and Genetical Aspects of Mycorrhizae (Gianinazzi-Pearson V, Gianinazzi S, eds), INRA, France, 363-368

Brown JC, Jones WE (1975) Phosphorus efficiency as related to iron inefficiency in sorghum. Agron J 67, 468-472

Brun R, Montarone M (1987) pH du milieu et réaction de la plante, différences spécifiques et variétales. In: Les Cultures hors Sol (Blanc D, ed) INRA, Paris, 153-170

Burstrom HG (1968) Calcium and plant growth. Biol Rev 43, 287-316

Carrodus BB (1966) Absorption of nitrogen by mycorrhizal roots of beech. I. Factors affecting the assimilation of nitrogen. New Phytol 65, 358-371

Chevalier S, Paris N (1981) Absorption et fixation du calcium par les chloroplates de lupin jaune (Lupinus luteus $L$ ) calcifuge et de féverole (Vicia faba L) calcicole. Physiol Veg 19, 23-31

Chilvers GA, Lapeyrie FF, Horan DP (1987) Ectomycorrhizal vs endomycorrhizal fungi within the same root system. New Phytol 107, 441-448

Clément A, Garbaye J, Le Tacon F (1977) importance des ectomycorhizes dans la résistance au calcaire du Pin noir (Pinus nigra Arn ssp nigricans Host). Acta Oecol Oecol Plant 12, 111-131
Coleman DC, Redi CPP, Cole CV (1983) Biological strategies of nutrient cycling in soil systems. Adv Ecol Res 13, 1-55

Cornell RM , Schindler PW (1987) Photochemical dissolution of goethite in acide/oxalate solution. Clays Clay Miner 35, 347-352

Cournier S, Grouzis JP, Rambier M, ParisPireyre N (1982) Relation entre la fixation de $\mathrm{Ca}^{2+}$, l'empilement des tylakoides et le caractère calcicole ou calcifuge chez deux espèces de vigne. Physiol Veg 20, 423-432

Dell B, Botton B, Martin F, Le Tacon F (1988) Glutamate dehydrogenases and nitrogen assimilation in spruce (Picea excelsa) and beech (Fagus sylvatica). New Phytol 1113, 683-692

Duchaufour P (1970) Précis de pédologie. Masson, Paris, $\mathrm{pp} 481$

Falade JA (1973) The effect of bicarbonate on ${ }^{32} \mathrm{P}$ uptake by tomato and runner ban. Ann Bot (Lond) 37, 341-344

France RC, Reid CPP (1979) Absorption of ammonium and nitrate by mycorrhizal and nonmycorrhizal roots of pine. In: Root Physiology and Symbiosis, Vol 6 (Riedacker A, Gagnaire-Michard J, eds), CNRF, Nancy, France, 336-345

France RC, Reid CPP (1983) Interactions of nitrogen and carbon in the physiology of $\mathrm{eC}-$ tomycorrhizae. Can J Bot 61, 964-984

Gavalas NA, Manetas $Y$ (1980a) Calcium inhibition of pyrophosphatase in crude plant extracts, implication of soluble calcium in $\mathrm{C}_{4}$ photosynthesis. Plant Physio/ 65, 860-863

Gavalas NA, Manetas Y (1980b) Calcium inhibition of phosphoenolpyruvate carboxylase: possible physiological consequences for $\mathrm{C} 4$ photosynthesis. Z Pflanzenphysiol 100, 179184

Gay G (1987) Influence d'un champignon ectomycorhizien, Hebeloma hiemale, et de I'AlA qu'il libère sur l'activité rhizogène de $P F$ nus halepensis; étude de la production d'AlA par ce champignon. Thèse de Docteur es Sciences, Université Lyon I

Graustein WC, Cromack K, Sollins P (1977) Calcium oxalate: occurrence in soils and effect on nutrient and geochemical cycles. Science $198,1252-1254$ 
Hager A, Hermsdorf $P$ (1981) $\mathrm{AH}+/ \mathrm{Ca}^{2+}$ antiporter in membranes of microsomal vesicles from maize coleoptiles, a secondary energized $\mathrm{Ca}^{2+}$ pump. $Z$ Naturforsch 36,1009 1012

Hall DA (1977) Some effects of varied calcium nutrition on the growth and composition of tomato plants. Plant Soil 48, 199-211

Hilbert JL, Martin F (1988) Regulation of gene expression in ectomycorrhizas. I. Protein changes and the presence of ectomycorrhizas-specific polypeptides in the PisolithusEucalyptus symbiosis. New Phytol 110, 339346

Jefferies RL, Willis AJ (1964) Studies on the calcicole-calcifuge habit. II. The influence of calcium on the growth and establishment of four species in soil and sand cultures. J Ecol 52 , 691-707

Jones D, Wilson MJ (1985) Chemical activity of lichens on mineral surfaces. A review. Int Biodeterior 21, 99-104

Jones D, Wilson MJ, Tait JM (1980) Weathering of a basalt by Pertusaria corallina. Lichenologist (Oxf) 12, 277-289

Katyal JC, Sharma BD (1980) A new technique of plant analysis to resolved iron chlorosis. Plant Soil 55, 105-119

Khalil N, Leyval C, Bonneau M, Guillet B (1989) Influence du type de nutrition azotée sur le déclenchement de la chlorose du sapin de Nordmann (Abies nordmanniana, Spach, 1842). Ann Sci For (Paris) 46, 325-343

Kianmher $\mathrm{H}$ (1978) The response of Helianthemum chamaecistus Mill to mycorrhizal infection in two different types of soil. Plant Soil 50, 719-722

Kinzel H (1983) Influence of limestone, silicates and soil pH on vegetation. In: Physiological Plant Ecology. III. Response to the Chemical and Biological Environment. Encyclopedia of Plant Physiology (Lange OL, Nobel PS, Osmond $C B$, Ziegler $H$, eds) New Series, vol 12C, Springer-Verlag, Berlin, 201-244

Krupa S, Fontana A, Palenzoma M (1973) Studies of the nitrogen metabolism in ectomycorrhizae: I. Status of free and bound aminoacids in mycorrhizal and nonmycorrhizal root systems of Pinus nigra and Coryllus avellana. Physiol Plant 28, 1-6
Krupa S, Branstrom G (1974) Studies of the nitrogen metabolism in ectomycorrhizae. II. Free and bound amino acids in the mycorrhizal fungus Boletus variegatus, in the root system of Pinus sylvestris, and during their association. Physiol Plant 31, 279-283

Lamant A, Cathala N, Salsac L, Heller R (1977) Application du fractionnement cellulaire à l'étude de la répartition des cations dans les racines de végétaux supérieurs. Physiol Vég $15,797-809$

Lamant A, Heller R (1975) Intervention des systèmes membranaires dans l'absorption du calcium par les racines de féverole (calcicole) et de lupin (calcifuge). Physiol Vég 13, 685-700

Lapeyrie FF (1987) Les mycorhizes de l'eucalyptus en conditions d'excès de carbonate de calcium. Approche écologique et physiologie des associés ectomycorhiziens. Thèse de Docteur es Sciences, Université Lyon I, pp 198

Lapeyrie FF (1988) Oxalate synthesis from soil bicarbonate by the mycorrhizal fungus Paxillus involutus. Plant Soil 110, 3-8

Lapeyrie FF, Bruchet G (1986) Calcium accumulation by two strains, calcicole and calcifuge, of the mycorrhizal fungus Paxillus involutus. New Phytol 103, 133-141

Lapeyrie FF, Chilvers GA (1985) An endomycorrhiza-ectomycorrhiza succession associated with enhanced growth by Eucalyptus dumosa seedlings plants in a calcareous soil. Now Phytol 100, 93-104

Lapeyrie FF, Chilvers GA, Behm CA (1987) Oxalic acid synthesis by the mycorrhizal fungus Paxillus involutus. New Phytol 106, 139-146

Lapeyrie FF, Chilvers GA, Douglass PA (1984b) Formation of metachromatic granules following phosphate uptake by mycelial hyphae of an ectomycorrhizal fungus. New Phytol 98, 345-360

Lapeyrie FF, Duclos JL, Bruchet G (1982) Influence du calcaire sur la croissance mycélienne de quelques champignons ectomycorhiziens et endomycorhiziens des éricacées. Les Colloques de I'INRA 13, 381390

Lapeyrie FF, Perrin M, Pepin R, Bruchet G (1984a) Formation de Weddellite en culture 
in vitro par Paxillus involutus (Batsch ex $\mathrm{Fr}$ ) $\mathrm{Fr}$; signification de cette production pour la symbiose ectomycorhizienne. Can J Bot 62 , 1116-1121

Lapeyrie F, Picatto C, Gérard J, Dexheimer J (1990) TEM study of intracellular and extracellular calcium oxalate accumulation by ectomycorrhizal fungi in pure culture or in association with Eucalyptus seedlings. Symbiosis (in press)

Le Tacon F (1978) La présence de calcaire dans le sol. Influence sur le comportement de l'epicéa commun (Picea excelsa Link) et du Pin noir d'Autriche (Pinus Nigra nigricans Host). Ann Sci For (Paris) 35, 165-174

Ling Lee M, Chilvers GA, Ashford AE (1975) Polyphosphate granules in three different kinds of tree mycorrhiza. New Phytol 75, 551-554

Malajczuk N, Cromack K (1982) Accumulation of calcium oxalate in the mantle of ectomycorrhizal roots of Pinus radiata and Eucalyptus marginata. New Phytol 92, 527-531

Marschner $H$ (1986) Mineral Nutrition of Higher Plants. Academic Press, London, $612 \mathrm{p}$

Martin F, Marchal JP, Tyminska A, Canet D (1985) The metabolism and physical state of polyphosphates in ectomycorrhizal fungi. A ${ }^{31} \mathrm{P}$ nuclear magnetic resonance study. New Phytol 101, 275-290

Martin F, Stewart GR, Genetet I, Le Tacon F (1986) Assimilation of ${ }^{15} \mathrm{NH}_{4}$ by beech ectomycorrhizas. New Phytol 102, 85-94

Mengel K, Breininger MT, Bubl W (1984) Bicarbonate, the most important factor inducing iron chlorosis in vine grapes on calcareous soil. Plant Soil 81, 333-344

Orlovich DA, Ashford AE, Cox GC (1989) A reassessment of polyphosphate granule composition in ectomycorrhizal fungus Pisolithus tinctorius. In: Plant-Microbe Interface: Structure and Function (McGee PA, Smith SE, Smith FA, eds), CSIRO Australia, 107-116

Oserkowsky J (1933) Quantitative relation between chlorophyll and iron in green and chlorotic pear leaves. Plant Physiol 8, 449-468

Piou D (1979) Importance de la mycorhization dans la résistance au calcaire de diverses espèces forestières. Rev For Fr 31, 116-125

Plassard C, Martin F, Mousain D, Salsac L (1986) Physiology of nitrogen assimilation by mycorrhiza. In: Physiological and Genetical Aspects of Mycorrhizae (Gianinazzi-Pearson V, Gianinazzi S, eds), INRA, France, 111120

Portis AR, Heldt HW (1976) Light dependent changes of the $\mathrm{Mg}^{2+}$ concentration in the stroma in relation to the $\mathrm{Mg}^{2+}$ dependence of $\mathrm{CO}_{2}$ fixation in intact chloroplasts. Biochim Biophys Acta 449, 434-446

Portis AR, Chon JC, Morbach A, Heldt HW (1977) Fructose and sedoheptulose biphosphatase. The sites of a possible control of $\mathrm{CO}_{2}$ fixation by light dependent changes of the stromal $\mathrm{Mg}^{2+}$ concentration. Biochim Biophys Acta 461, 313-325

Rhoads WA, Wallace A (1960) Possible involvement of dark fixation $\mathrm{CO}_{2}$ in lime-induced chlorosis. Soil Sci 89, 248-256

Robert M, Razzaghe MK, Vicente MA (1979) Rôle du facteur biochimique dans l'altération des minéraux silicatés. Sci Sol 2, 153-174

Rossignol M (1977) Mesure de la fixation du calcium sur les phospholipides extraits des racines de lupin jaune et de féverole. Physiol Vég 15, 811-816

Rossignol M, Lamant D, Salsac L, Heller R (1977) Calcium fixation by the roots of calcicole and calcifuge plants: the importance of membrane systems and their lipid composition. In: Transmembrane lonic Exchange in Plants (M Thellier, A Monnier, M Demarty, J Dainty, eds) Editions du CNRS, Paris and Éditions de l'Université, Rouen, 483-490

Rygiewicz PT, Bledsoe CS (1984) Mycorrhizal effects on potassium fluxes by northwest coniferous seedlings. Plant Physiol 76, 918-923

Rygiewicz PT, Bledsoe CS, Zasoski RJ (1984a) Effects of ectomycorrhizae and solution $\mathrm{pH}$ on ${ }^{15} \mathrm{~N}$ nitrate uptake by coniferous seedlings. Can J Bot 14, 893-899

Rygiewicz PT, Bledsoe CS, Zasoski RJ (1984b) Effects of ectomycorrhizae and solution $\mathrm{pH}$ on ${ }^{15} \mathrm{~N}$ ammonium uptake by coniferous seedlings. Can J Bot 14, 885-892

Salsac $J$ (1973) Absorption du calcium par les racines de Féverole (calcicole) et de lupin jaune (calcifuge). Physiol Veg 11, 95-119

Salsac $L$ (1980) L'absorption du calcium par les racines des plantes calcioles ou calcifuges. Sci Sol 1, 45-77 
Salsac L, Mention M, Plassard C, Mousain D (1982) Données sur la nutrition azotée des champignons ectomycorhiziens. Les Colloques de l'INRA, 13, 129-140

Strullu DG, Harley JL, Gourret JP, Garrec JP (1982) Ultrastructure and microanalysis of polyphosphate granules of the ectomycorrhizas of Fagus sylvatica. New Phytol 92, 417423

Szaniszlo PJ, Powell PE, Reid CPP, Cline GR (1981) Production of hydroxamate sidero- phore iron chelators by ectomycorrhizal fungi. Mycologia 73, 1158-1174

Vésina LP, Margolis HA, McAfee BJ, Delaney S (1989) Changes in the activity of enzymes involved with primary nitrogen metabolism due to ectomycorrhizal symbiosis on jack pine seedlings. Physiol Plant 75, 55-62

Watteau F (1990) Production de sidérophores dans les sols acides et calcimagnésiques et altération de minéraux par des champignons ectomycorhiziens. Thèse, Nancy I, $111 p$ 